\title{
Metaphorical Awareness: A New Horizon in Vocabulary Retention by Asian EFL Learners
}

\author{
Natasha Pourdana (Corresponding author) \\ Department of English Translation, College of Literature and Foreign Languages, Islamic Azad University, Karaj Branch, Alborz, Iran \\ Global Education Center, Gyeongju University, South Korea \\ E-mail: natasha.qale@gmail.com
}

Somayeh Sahebalzamani

Samina.saheb@gmail.com

John S. Rajeski

asiajsr@gmail.com

Received: 10-02- 2014

doi:10.7575/aiac.ijalel.v.3n.4p.213
Accepted: 05-04- 2014

Published: 01-07- 2014

\begin{abstract}
The present study investigates the impact of English metaphorical awareness on the vocabulary retention by 60 intermediate EFL learners in Iran. Participants in this study were all English as a Foreign language (EFL) learners placed in the intermediate level of both genders ranging from 16 to 20 years of age at Qeshm language institute, Kerman, Iran. An Oxford Placement Test (OPT) was administered to homogenize the participants and divided them into two intact experimental and control groups. The experimental group was exposed to and performed on 20 minutes English metaphorical awareness tasks of Pictorial Idioms, Poems, and Matching in sixteen 90-minute sessions. The controllgroup received the vocabulary exercises in New Cutting Edge ( $3^{\text {rd }}$ Edition) (Cunningham, Moor \& Eales 2007) in turn The experimental group outperformed the controlgroup in this study. In an independent sample t-Test, and a high effect size (Cohn's d=2.84) supported the positive impact of metaphorical awareness on EFL learners' vocabulary retention.
\end{abstract}

Keywords: Awareness, EFL, Idiom, Matching, Metaphor, Poetry, Retention, Task, Vocabulary

\section{Introduction}

How to learn vocabulary effectively is one of the most delicate and crucial English as a Foreign Language (EFL) endeavors. Krashen (1982:44) argues that as "language learners do not carry grammar books in their pocket, they always carry dictionaries". Likewise, while without grammarvery little can be transmitted, without vocabulary nothing can be delivered. In recent years, ample studies in cognitive linguistics provoked the foreign language vocabulary acquisition and retention.

Vocabulary refers to a set of lexems including single words, compound words, and idioms (Richards \& Schmidt 2002). Accordingly, vocabulary learning is defined as the complex acquisition process of words pronunciation and meaning as well as their metaphorical and stylistic properties (Wallace 1982, Kalyuga 2006). To have a fundamental undestanding of a language at the conversational level, a vocabulary of around 5000 words seems necessary (Pimsleur 1980). Children, who live and immerse every waking hour into an ideal environment for acquiring their first language, successfully learn at a rate of around 10 new words per day (Carey 1978). These facts and a back-of-the-envelope calculation reveal that vocabulary acquisition should last at least for a couple of years in a language learner's life. It is no wonder that the first few years of foreign language learning are often characterized by having a constant focus on language bits and pieces at lexical level (Brindly et al. 1988).

Think of vocabulary, EFL learners bitterly remember memorizing a long list of new words with their equivalent meanings in their native language without any real context practice. A number of learners may share even worse experience of looking up every individual word in a bilingual dictionary to find their meanings or equivalents whenever they encounter them in a passage. They may even write down rows of new words without speculating their real use in real contexts. Soon after many language learners figure out that vocabulary in the list does not satisfy their needs, and they could think of their bad memories as the only possible reason (Gnoinsk 1998). DeCarrico (2001) states that words should not be learnt individually or by memorizing without situational understanding. Moreover, learning new words is a cumulative process, with words enriched and internalized as they are met again in a new context. Therefore, the longstanding old-fashioned "look and remember" way of vocabulary learning seems not to be very effective for EFL learners (Nation 2001). 
In a conventional teacher-centered classroom, the EFL learners likely require their teachers to provide the meaning and grammatical functions of new words. They are even dependent on the teacher to assist them with the spelling of the new words before writing those words in their notebooks or complete the exercises. They usually expect to use words in the original forms they have learned. This kind of rote verbal memorization is acceptable to certain extent as it helps novice learners to practice and use the correct form of words. However, it is an artificial vocabulary acquisition since only the grammatical and phonological aspects of the words are emphasized; the lexical aspect is usually neglected. In other words, while the learners learn how to use a word in its exact form in a certain situation, they are not expected to accumulate its different shades of meaning for real life communication (DeCarrico 2001).

Many language teaching curricula desperately leave the problem to their students as homework and little instruction is given as the effective acquisition techniques. According to Anderson and Nagy (1992), teachers are reluctant to waste the valuable class time for explicitly teach individual words when the impact of expository instructions seems negligible relative to the sheer number of words a student needs to learn. As a result, students often resort to rote memorization to prepare for classroom activities or take final tests.

In recent years, evolutionary studies in cognitive linguistics and SLA have facilitated foreign language vocabulary acquisition and retention. They put more emphasis on how metaphorical awareness can increase the speed and efficiency of vocabulary learning. A large number of studies have backed up the positive influence of the knowledge of conceptual metaphors on EFL learners' ability to learn and acquire polysemic words and idiomatic expressions (e.g., Boers 2004, Csabi 2003, Kovescses \& Szabo 1996, Herrera \& White 2000).

Metaphors are excessively used in everyday communication. Most universal and basic concepts of the world such as time, state and quantity are thoroughly understood through metaphorical mapping. Generally speaking, our cognitive processes or the way we think, act, perceive and view the world are based on our metaphorical concepts that structure and influence the speech language. Our conceptual system, therefore, plays a radical role in defining our everyday realities. Therefore, metaphor as an important intellectual element in language use is regarded as a constructive phenomenon in everyday language (Lakoff \& Johnson 2003). Metaphor produces a magical power that creates new realities by affecting our perceptions, thoughts and ideas about the world. Metaphor is a multifaceted tool of explaining, describing and evaluating ideas to better understand and communicate abstract entities in our everyday activities.

Lakoff and Johnson (2003) believe that most conceptual metaphors have originally been developed to reflect the basic human experiences and they seem identical in different alive languages. According to their paradigm of cognitive semantics (2003), metaphor is a fundamental cognitive ability which allows us to talk and think about abstract concepts and phenomena. Some metaphors are so deeply entranced in human thoughts that they have been called Metaphor We Live By (Lakoff \& Johnson 1980) or conceptual metaphors (Lakoff 1987). This cognitive approach to celebrate metaphors and idioms is strongly believed to facilitate vocabulary learning and long-term retention (Kovecses 2001). Gibbs (1993a, 1994) also argues that people can hardly avoid metaphors in their daily speech because they conceptualize and later internalize most of their abstract thoughts in terms of metaphors, metonymys and idioms. Similarly, Richards and Schmidt (2002) believe that a language learner with such metaphorical awareness can easily identify and produce metaphorical language in various forms of nominal, verbal, or adverbial.

As Hashemian and TalebiNezhad (2006) state, a lack of metaphorical awareness is usually counterproductive and commonly misleads Iranian EFL learners to represent metaphorical expressions in English by an analogous counterpart in Persian as their first language. Therefore, the equivalent for an English word or sentence is literally translated by resorting to the Persian concepts due to inadequate knowledge of all possible meanings for a word or expression. They conclude that obtaining the knowledge of idiomatic language is a big step to successful language learning (Hashemian and TalebiNezhad 2006).

EFL learners, accordingly, should be encouraged to make use of their metaphorical language "to produce and comprehend metaphors as tools of communication and thought" (Stight 1979). Boers (2000) points out that in EFL classroom it is effective for learners' vocabulary retention to present relatively new metaphorical expressions along with their metaphorical theme or source domain. He holds that the application of cognitive factors in EFL teaching, such as metaphorical awareness, should be advocated to substitute traditional vocabulary memorizing. Further studies by Boers (2004) promoted long term and short term vocabulary enlargement, receptive and productive vocabulary, EFL learners' English proficiency level, cognitive style as well as the vagueness of vocabulary based on the result in his previous works.

In EFL vocabulary learning, "the concept of learning burden of a word is defined as the amount of mental efforts required to learn that word" (Nation 2001: 30). It is determined by the level of learners' prior knowledge of language and familiarity with similar patterns (e.g., similar sounds, spelling and collocation in their first language). This learning burden can be substantially reduced by directing EFL learners' attention to systematic patterns, analogies and connections between the first and foreign languages (Laufer 1997, Nation 2001).

Having an adequate perception of the human cognitive system is necessary for developing and maintaining effective approaches to teaching vocabulary and vocabulary retention. The human cognitive system includes several basic components that are actively involved in any learning process, including sensory memory, working or short term memory, and long term memory. Working memory is "the major conscious cognitive processor responsible for constructing and integrating mental representations and short term storage and maintenance of the relevant information" (Baddeley:42 1986). Working memory is extremely limited in capacity and duration when it deals with unfamiliar 
information. For example, we can hardly recall more than approximately seven to nine randomly presented words (Miller 1956). Even this limited number of items will be lost within a few seconds, unless they are intentionally rehearsed. Long term memory stores the learned information in the form of a well-organized domain of specific knowledge structures and is virtually unlimited both in capacity and duration. An organized knowledge structure (schema) allows us to accommodate several related bits of information into single chunks (Miller 1956).

Hornby (2004) simply defines retention as the ability to remember things. As an operational definition in language learning contexts, retention is the ability to recall or remember the foreign langugae words after a rather long time interval. As Thornbury (2004) indicates, there are two factors that determine retention: First, those words that are easier to learn are better retained. Secondly, those words that are learned over spaced learning sessions are retained better than words that are learned intensively in concentrated bursts. He states that one of the routs which move the materials into the permanent long term memory is imaging or visualizing a mental picture for a new word in order to make it more memorable.

According to Oxford (1990), memorizing strategies, traditionally known as mnemonics, have been around since ancient times. They involve linking the new words to some previously learned knowledge while their ultimate goal is organization and establishment. In a traditional language teaching classroom, memorizing strategies such as acronym, grouping and imagery which help learners store and retrieve information are major techniques to enhance short-term and long-term retention. Acronym or forming a real or nonsense word from the first letters of a list of words is not a very helpful practice to understand the meaning but only to memorize and remember the words. Grouping words also makes them possible to remember. It breaks down a large number of language blocks into small meaningful bricks in order to make the information simple to remember by reducing the number of trivials. Imagery commonly refers to linking a list of items to concepts in memory by picturing them together or separately. Employing meaningful pictures either in mind or in actual drawings is believed to create better memorization and retention (Oxford 1990).

The importance of metaphors in vocabulary learning is recently acknowledged and emphasized by a number of EFL researchers. Experiments by Boers (2004), for instance, argue that a vast metaphorical awareness may lead to a much better vocabulary learning. A deeper comprehension of the conceptual and cultural aspects of a language is a key factor in learning metaphors. If learners learn some metaphorical expressions that are augmented by their general concepts, for example, 'life is magic', it would be easier for them to retain expressions such as 'she casts her spell over me' (Lakoff \& Johnson 2003).

Metaphors, however, are not easy to learn. Hamamoto (2004) lists some lumps and bumps on the road: (1) Learning metaphor seems to be closely integrated to that concepts and impressions that are lied on particular aspects of a culture. (2) Some metaphors have their roots not only in culture but also in the social environment of the time they are created. This restricted timeline makes them even more difficult for non-native speakers to comprehend. (3) Learners are often incapable of evaluating whether a statement is meant to be a creative or individual metaphor, a joke, an ironical expression or a literal one. Native speakers of the language can infer the intention of the speaker or a writer by the way the metaphorical expression is presented in the context. This apparently simple process requires a high level of language competence for language learners.

Several studies counterargue the benefits of metaphors for English learners who appear to have considerable difficulties in comprehending and producing idioms accurately (Irujo 1986, 1993). Sadeghilar (1993) focuses on the application of translation in the process of learning idioms and reports that identical idioms in both English and Persian would show positive transfer since they are the easiest to comprehend and produce effectively. Disimilar idioms would show negative transfer and their comprehension is as easy as identical idioms, but their production reflects interference with Persian. Working with EFL learners at universities as his subjects, the current researchers conducted some research on how to present metaphorical idioms in language classrooms. The results showed that a mastery of the origin and formation of idioms is conductive to the acquisition and retention of the expression.

\section{Method}

\subsection{Participants}

A quasi-experimental research, this study was conducted with an intact group of 66 EFL learners in Qeshm Language Institute, Kerman, Iran, 2011. They were selected based on convenient sampling from the population of intermediate students $(\mathrm{N}=78)$. The subjects were from both male and female genders ranging from 16 to 19 years of age to minimize the subjects' age effect. The English proficiency level of participants was pre-tested with the Oxford Placement Test (OPT). The participants scores on OPT were later used to homogenize them by excluding the scores two standard deviations beyond the mean $(\mathrm{N}=6)$.

\subsection{Instruments}

The subjects were required to take an Oxford Placement Test (OPT) as a test of homogeneity in this study. While the control group were supposed to go through exercises presented in New Cutting Edge ( $3^{\text {rd }}$ Edition) (Cunningham, Moor \& Eales 2007) as their English textbook, the experimental group received 20 minute instructions on metaphorical awareness through images, poems and matching exercises for 16 sessions.

(a) Images: The intended metaphors were chosen carefully from 101 American English Idioms (Collis 1987). Five idiomatic expressions were taught during the first 8 sessions (Appendix A). 
(b) Poems: The next 8 sessions, the experimental group were given almost one poem every session. All poems were selected from Literature: The Elements of Poetry (Perrine 2002). Every session, the researcher read and discussed the present metaphors and metaphorically based stanzas (Appendix B).

(c) Matching: Every session, the subjects were given two matching tasks as their homework. They were about food, health, color, and the like. They were selected from Idioms Organizer (Wright 1999) (Appendix C).

The researchers constructed and piloted the post-test (Cronbach $\alpha=0.82$ ). The content of the test was selected from Intermediate Vocabulary (Thomas 1995). Thirty fill-in-the-blank and multiple choice items in the test measured the subjects' retained knowledge of vocabulary. It was administered for 30 minutes in the last session (Appendix D).

\section{Results and Discussion}

In order to analyze the scores on OPT and the post-test by both experimental and controlgroups, the SPSS 19 was used. Later, the possible differences in the performance of two groups was examined through $t$-test.

Table 1. OPT: Descriptive statistics

\begin{tabular}{cccccc}
\hline $\mathrm{N}$ & Mean & Std. Deviation & Variance & Min & $\max$ \\
\hline 66 & 59.78 & 8.36 & 70.01 & 42 & 78 \\
\hline
\end{tabular}

As Table 1 shows, the initial 66 participants came up with the minimum score of 42 and maximum score of 78 out of 100. In order to determine the homogeneity of the subjects and to extract the outliers, the researchers selected only 60 subjects whose scores were within two standard deviations above and below the mean score.

Table 2. Post Test: Descriptive statistics

\begin{tabular}{lllccc}
\hline & Groups & $\mathrm{N}$ & Mean & Std. Deviation & $\begin{array}{c}\text { Std. Error } \\
\text { Mean }\end{array}$ \\
\multirow{3}{*}{ Post Test } & Control & 30 & 11.16 & 4.20 & .76 \\
& Experimental & 30 & 22.56 & 4.01 & .73 \\
\hline
\end{tabular}

In Table 2, post-test scores for experimental and control groups are presented. To determine the effect size of the treatment (Rosental 1994), the cohen's d which measures the differences between two independent sample means was calculated. Cohen's d=2.84 shows a large effect size (Larson-Hall 2011). All the scores on post tests were examined with Kolmogrov-Smirnov test of normality. Kolmogorov-Smirnov Z of .049 ( $p$-value=.966) for the controlgroup, and .0965 ( $\mathrm{p}$-value $=.309)$ for the experimental group, both insignificant at $\mathrm{p}$-value $<.05$, allowed the Independent Samples TTest in this study.

Table 3. Independent samples $t$-test

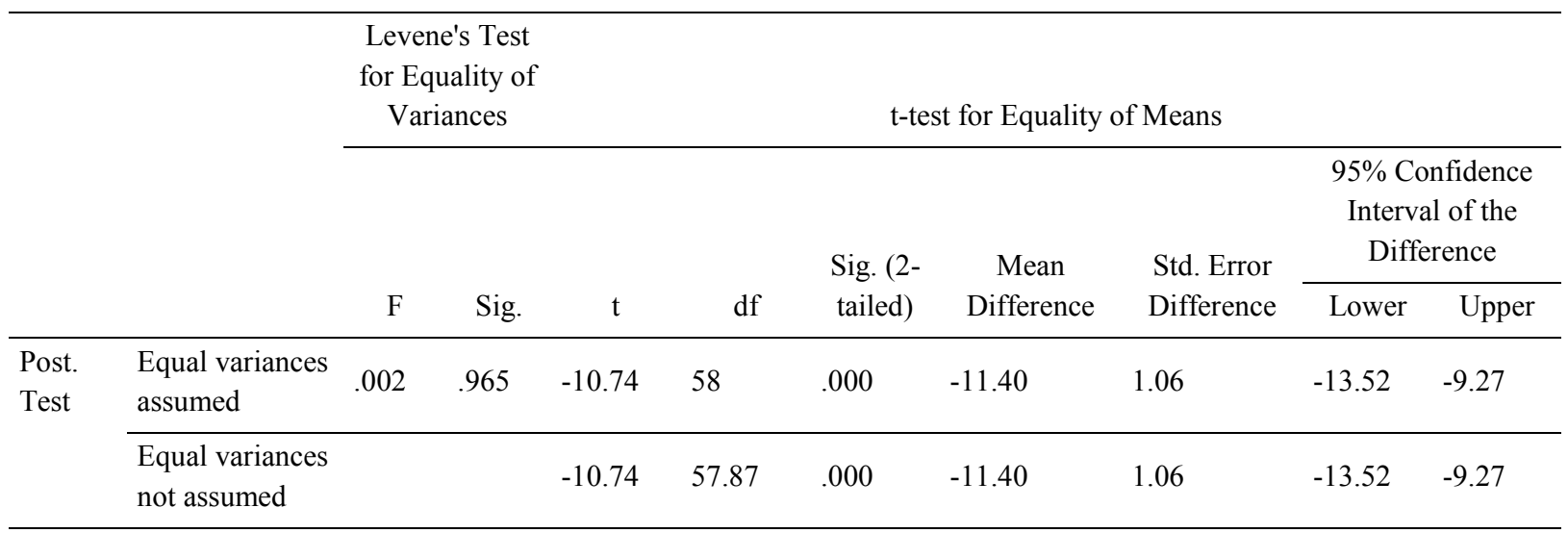

As Table 3 shows, the $t$-value $(-10.74)$ is statistically significant at p-value $<0.05$ which can be interpreted as a better performance of experimental group on the post test. Findings in this study support a positive impact of metaphorical awareness on EFL learners' vocabulary retention. The results also tacitly support introducing new words and expressions in chunks, on the basis of a shared metaphorical theme such as reading poem, introducing idioms through picture, and teaching verbal information through imagery as an extra pathway for recalling vocabulary. On the other hand, using techniques to enhance metaphorical awareness, the EFL teachers can lessen students' anxiety in language classrooms and make the environment more enjoyable by involving students more meaningfully and effectively. 
Metaphorical awareness helps EFL learners feel more content about learning frequently used words in daily conversations in real settings by English native speakers.

\section{Conclusion}

The present study investigates whether metaphorical awareness positively affects EFL vocabulary retention. Findings in this study help EFL teachers to have a better view of using various types of metaphors such as idioms or poetry in EFL classrooms. Secondly, metaphorical awareness can freely be used to practice four language skills of writing, reading, speaking and listening. EFL material developers subsequently can benefit from the possible advantages endowed with presenting metaphors in English textbooks pages. Therefore, this research manages to account the differences metaphorical awareness has made in teaching EFL vocabulary to Iranian intermediate learners of English as Foreign Language (EFL).

\section{References}

Anderson, R.C., \& Nagy, W.E. (1992). The vocabulary conundrum. American Education 16 (4), pp.44-47.

Boers, F. (2000). Metaphor awareness and vocabulary retention. Applied Lingustics, 21, pp. 553-571.

Boers, F. (2004). Expanding learners' vocabulary through metaphor awareness: what expansion, what learners, what vocabulary? A cognitive linguistic view of polysemy in English and its implications for teaching. In Cognitive Linguistics, Second Language Aqcuisition, and Foreign Language Teaching, (Ed.), pp.211-32.

Brindly, G., Pienemann, M., \& Johnston, M. (1988). Constructing an acquisition-based procedure for assessing second language acquisition. Studies in Second Language Acquisition 10, pp.143-217.

Carey, S. (1978). The child as word-learner. In M. Halle, J. Bresnan, \& G. Miller (Eds.), Linguistic Theory and Psychological Reality, (pp. 264-293). Cambridge, MA: MIT Press.

Csabi, S. (2003). A cognitive linguistic view of polysemy in English and its implications for teaching M. Archard, \& S. Neineier, (Eds.). Cognitive Linguistics, Second Language Aquisition and Foreign Language Teaching. (pp. 233-256). Berlin- New York: Mouton de Gruyter.

Cunningham, S., Moor, P. \& Eales, F. (2007). New Cutting Edge ( $3^{\text {rd }}$ Ed). London: Harlow.

DeCarrico, J. (2001). Vocabulary learning and teaching. In M. Celcia-Murica (Ed.), Teaching English as a Second Or Foreign Language ( $3^{\text {rd }}$ Ed.), (pp. 285-299). Boston, MA: Heinle \& Heinle Publisher.

Gibbs, R.W. (1993a). Why idioms are not dead metaphors In G. Cacciari, \& P. Tabossi, (Eds.), Idioms: Processing, structure and interpretation.(pp.57-76) Hillsdale London: Lawerence Erlbaum Associates.

Gibbs, R.W. (1994). The poetic of mind: figurative thought, language and understanding. Cambridge: Cambridge University Press.

Gnoinska, A. (1998). Teaching vocabulary in colour. English Teaching Forum, 36 (3), pp. 12-15. Retrieved December 21, 2011, http://dosfan.lib.uic.edu/usia/E-USIA/forum/vols/vol36/no3/p12.htm

Hamamoto, S. (2004). Enhancement of metaphor awareness in the classroom. Birmingham: Birmingham University.

Hashemian, M. \& Talebi Nezhad, M. R. (2006). The development of conceptual fluency and metaphorical competence in L2 learners. Linguistik online, 30, pp.1-60.

Herrera, H. \& White, M. (2000). Cognitive linguistics and the language learning process: A case from economics. Estudios Ingleses de la Universidad Complutense, 8, pp.55-78.

Irujo, S. (1986). "A piece of cake: learning and teaching idioms". ELT Journal,40(3), pp. 236-42.

Irujo, S. (1993). "Steering clear: avoidance in the production of idioms". IRAL, 31(3), pp.205-219.

Kalyuga, S. (2006). Instructing and testing advanced learners: A cognitive load approach. New York: Nova Science.

Kovecses, Z. (2001). A cognitive linguistics view of learning idioms in an FLT context. .87-116. M. Putz, M. Nieneir, \& R. Dirven, (Eds.). Applied Linguistics II: Language Pedagogy. Berlin- New York: Mouton de Gruyter.(2005). Metaphor in culture: Universality and Variation. Cambridge: Cambridge University Press.

Kovecses, Z. \& Szabo, P. (1996). " Idioms: a view of cognitive semantic." Applied Linguistics, 17(3), pp.326-55.

Krashen, S. (1982). Principles and practice in second language acquisition. Oxford: Pergamen.

Lakoff, G. (1987). Women, Fire, and dangerous Things: what categories reveal about the mind. Chicago: Chicago University Press.

Lakoff, G. \& Johnson, M. (1980). Metaphor We Live By. Chicago: Chicago University Press.

Lakoff, G. \& Johnson, M. (2003) 'Afterword' in Metaphors We Live By. Chicago:Chicago University Press.

Larson-Hall, J. (2011). A guide to doing statistics in second language research using SPSS London: Routledge.

Laufer, B. (1997). Why are some words more difficult than others? Some intralexical factors that affect the learning of words. International Review of Applied Linguistics, 28,pp.293-307. 
Miller, G.A. (1956). The magical number seven, plus or minus two: some limits on our capacity for processing information. Psychological Review, 63, pp.81-97.

Nation, I. S. P. (2001). Learning vocabulary in another language. Cambridge, UK: Cambridge University Press.

Oxford, R. (1990). Language learning strategies: What every teacher should know. New York: Newbury House Publishers.

Pimsleur, P. (1980). How to learn a foreign language. Boston: Heinle \& Heinle Publishers.

Richards, J. C. \& Schmidt, R.(2003). Longman dictionary of language teaching and applied linguistics (3 $\left.{ }^{\text {rd }} \mathrm{ed}.\right)$. London: British Library Cataloguing in Publication Data.

Rosenthal, R. (1994). Parametric measures of effect size. In H. Cooper \& L. V. Hedges (Eds.), The Handbook of Research Synthesis (pp. 231-244). New York: Russell Sage Foundation.

Sadeghi, B. (2010). Patterns of Persian EFL learners' comprehension of idiomatic expressions: Reading strategies and cross-cultural mapping in focus. University of Isfahan. Asian Social Science, 6, pp.89-101.

Stight, Th. G. (1979). Metaphor and Thought: Educational uses of metaphor. Cambridge: Cambridge University Press.

Thomas, B. J. (1995). Intermediate Vocabulary. Longman: HarLow.

Thornbury, S. (2004). Natural grammar:The keywords of English and how they work.Oxford: Oxford University Press.

Wallace, M. J. (1982). Teaching vocabulary. London: Heinemann Educational Books.

Wright, J.(1999). Idioms Organizer. England: Language Teaching Publications.

Appendix A

Treatment: Examplar Image

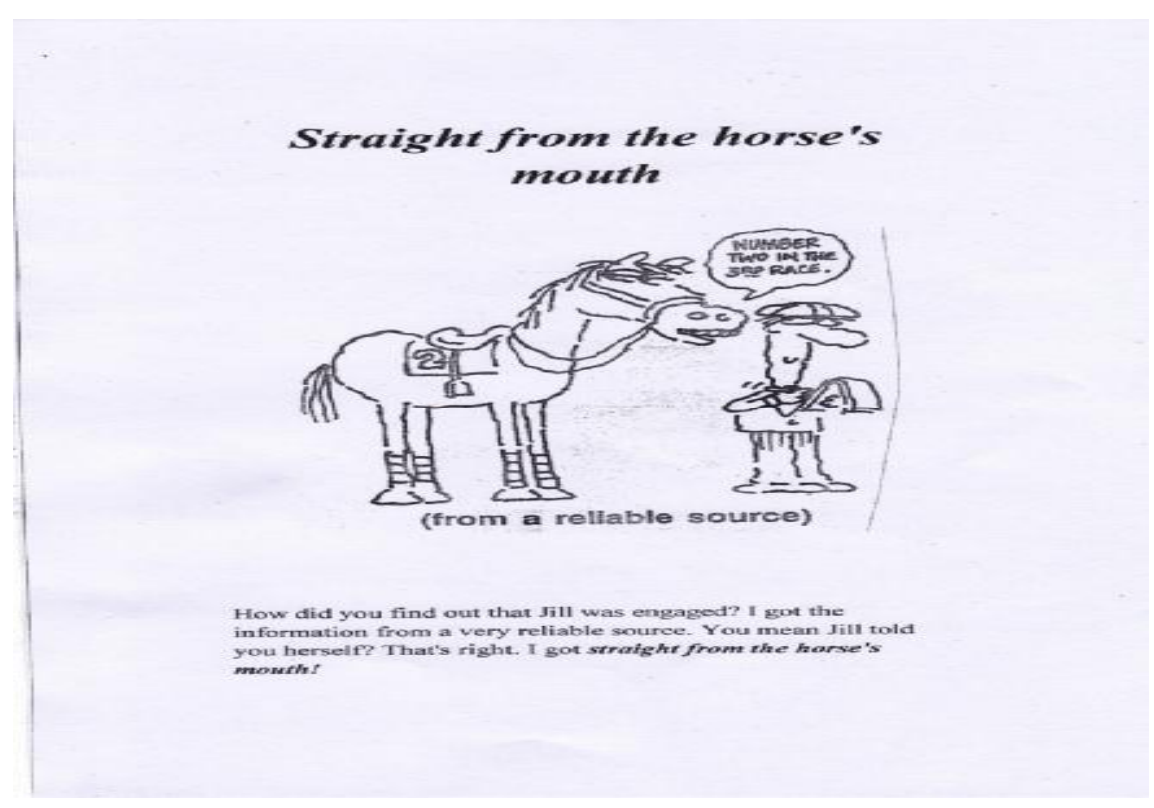

Appendix B

Treatment: Examplar Peom

THE HOUND

\section{Life the hound}

Equivocal

Comes at a bound

Either to rend me

Or to befriend me.

I can not tell

The hound's intent

Till he has sprung

At my bare hand

With teeth or tongue.

Meanwhile I stand

and wait the event. 


\section{Appendix C}

Treatment: Examplar Matching Task

\section{Read the following statements carefully.}

1. All Mark talked about the whole evening was football!

I was bored to death.

2. You should get the brakes fixed on your car. You are dicing with the death every time you go out on the road.

3. Are you ill? You look like death warmed up.

4. A. So you met my colleague Tony yesterday.

B. yes, he was a lot of fun he's a real larger than life character, isn't he?

5. A. Taking up golf since I retired has given me a new lease of life.

\section{Match the following definitions to the idioms.}

1. Bored to death

2. Dicing with the death

3. Like death warmed up

4. Larger than life

5. A new lease of life a. a chance to live or last longer or with higher quality of life

b. extremely tired and bored

c. to risk one's life

d. very extraordinary person

e. A person looks very tired or sick and going to die

\section{Appendix D \\ Post Test}

Part A. Put each of the following words or phrases in its correct place in the passage below.

unemployment dispute go on strike dead-end job dismiss deadlock shop steward on the dole redundant gates

The 1,600 workers at the Ace Cycle Factory decided to -------1------- last week following a --------2------ With the management, who last month decided to --------3-------- two men for unsatisfactory workand a --------4-----. The men complained to their ---------5---------, who told the union. The management and the union have had talks but these soon ended in -------6------. The area in which the factory is situated is really an area of high -------7------, with one adult in five --------8-------- (out of work and receiving state aid). The striking workers have formed a picket line outside the. Factory..... 9..... to prevent other workers from going in to work. The management said that $20 \%$ of The workers will have to be made -------10------ next year anyway because of the decreased demand for cycles.

\section{Part B. Choose the best meaning for the underlined words or sentences.}

1. I love my new job, the people, the work, the money. The fact they've given me the car of my dreams, it $\mathrm{s}$ just the icing on the cake.

a. decorating a cake with the butter.

b. the best and attractive but unnecessary addition to something that is already satisfactory.

c. the best and attractive but unnecessary addition to something that is already unsatisfactory.

d. the worst thing that happens.

2. Bad news, Dad! I want to divorce. Carol told me last night she didn't want to see me anymore. Never mind dear son. There is plenty of fish in the sea.

a. there are many things or people as good as on that you had failed to get.

b. there is not any more opportunity.

c. there is not any chance for you.

d. loosing chance.

3. The trucking industry was considered to be unstable, chaotic, and in need of regulation.

a. the best situation

b. completely disordered or confused

c. completely good

d. completely changeable

4. He is the true benefactor of racism and orphans.

a. a person who gives money or other help to a school, hospital, charity, etc.

b. a person who lends money or other help to a school, hospital, charity, etc.

c. a person who borrows money or other help from a school, hospital, charity, etc.

d. non of them. 
5. Is says in the paper that our financial situation has never been better. Statistic shows that around 70 percents of people are living on the breadline in Pakistan.
a. people with high salary.
b. rich people
c. beggar people
d. poor people with low salary

6. Jack finds a new job nowadays, but he is not serious about his work. Somehow he is lazy. So his supervisor says him: "shape up or ship out".

a. behave properly or stay

b. behave properly or leave

c. behave normally and go away

d. $a$ and $b$

7. They went to poetry reading. But they got bored and restless. As far as they were concerned, it was for the birds.

a. interesting and meaningful

b. interesting but meaningless

c. uninteresting and meaningless

d. uninteresting but meaningful

8. Sometimes, advertisers impact society by the use of advocacy ads, whose purpose is not to persuade the public to buy a product, but to change the public's view about a specific issue.
a. convince
b. let
c. allow
d. bias

9. We encountered the Smiths before leaving the parking lot.
a. to find somebody in parking lot
b. to meet somebody unexpectedly
c. to meet somebody expectedly
d. to face somebody expectedly

10. For some people, to do stealing and killing duck soup for them.
a. hard
b. difficult
c. easy
d. $a$ and $b$

\section{Part C. Choose the best answer.}

1. I like to travel all over the world, because in my opinion, variety is the spice of -------------.
a. live
b. life
c. living
d. food

2. She doesn't feel ok. She must take some pills, because she looks as white as
a. paper
b. snow
c. sheet
d. chalk

3. All Mark talked about football game and I cooked and cleaned, I was really bored to
a. death
b. dead
c. die
d. sick

4. I refused Bob's invitation because of his manner and I told him: " go fly a
a. bird
b. kite
c. plane
d. sky

5. How did you find out that Jill was engaged? I got the information from the reliable source. I got straight from the -------o- mouth.
a. cat's
b. dog's
c. elephant's
d. horse's

6. I was invited to be a judge for the best amateur painter. Oh, really? Come on, you are ------------ my leg.
a. pulling
b. pushing
c. keeping
d. taking

7. Her son comes home late at night around 2:30. She nags all the time and -
a. jumps over
b. jumps down
c. jumps up
d. jumps -his throat.

8. It is no wonder you have a stomachache. I told you not to eat so many green apples. You don't listen and now you have to --------- the music.
a. listen
b. hear
c. play
d. face

9. It is my birthday party. I want to wear my finest clothes, because all my friends are dressed to
a. kill
b. die
c. dance
d. live

10. Julie had always felt that she was missing out on a lot of fun, but finally she - the bull by the horns.
a. pulled
b. took
c. pushed
d. gave 